\title{
Response of Rooting of Various Olive Cultivars to Iba (Indol Butaric Acid)
} \author{
Rizwan Ullah Zahir ${ }^{4}$ and Muhammad Nouman Shuaeb ${ }^{1}$ \\ ${ }^{1}$ Department of Horticulture, University of Agriculture Peshawar, Pakistan \\ ${ }^{2}$ Department of Agricultural and Applied Economics, University of Agriculture Peshawar, Pakistan \\ ${ }^{3}$ Department of Agronomy, University of Agriculture Peshawar, Pakistan \\ ${ }^{4}$ Department of Horticulture, Gomal University, Pakistan
}

Shahab Jan ${ }^{1 *}$, Muhammad Ilyas ${ }^{1}$, Imran Khan Samar ${ }^{2}$, Nawab Ali ${ }^{3}$, Muhammad Mehran Anjum ${ }^{3}$, Asad Ullah ${ }^{1}$,

Submission: June 13, 2017; Published: July 31, 2017

"Corresponding author: Shahab Jan, Department of Horticulture, the University of Agriculture Peshawar Pakistan, Amir Muhammad Khan Campus Mardan, Pakistan, Email: shbjan789@gmail.com

Abstract

A research study "The Response of Rooting of Various Olive Cultivars to IBA "was carried out at Agriculture Research Institute Tarnab, Peshawar in 2016. The experiment was laid out in Randomized Completely Block Design (RCBD). The olive cutting was planted in July 19 th 2016. The data recorded for various parameters are summarized below. The data was recorded the following parameters i-e Sprouting (\%), Rooted Cutting, Root Length (cm), Successful plant percentage (\%) Maximum number of Sprouting percentage (84.6), Rooted Cutting (38.3), Root Length $(92.20 \mathrm{~cm})$, and Successful plant percentage $(32.3)$ was observed in those plant which were planted by us in July 19 2016.2 .

Keywords: Olive; Cultivars and rooting

\section{Introduction}

Olive (Oleaeuropaea) locally called Zaitoon or Khuna belongs to the family Oleaceae is one of the ancient cultivated fruit trees. Its domestication started approximately 6500 years ago [1]. It originated from Palestine, Lebanon, North West Syria and Cyprus [2]. Olive is a medium sized to tall evergreen tree that can reach a height of $15 \mathrm{~m}$ or more. It is a robust tree that is capable of regenerating promptly if cut or injured above ground and can live for centuries while maintaining good productivity. Its leaves are dark green, thick, leathery, lanceolate and oppositely arranged [3].

Olive growing plays in important role in the economy of a country. It can be grown in marginal and waste land, where the soil is unsuitable for other crops. It increases the land value. It contributes to soil conservation and helps to combat problems of the environmental degradation and desertification. It provides employment opportunities to the rural population and thus helps in poverty alleviation. A large number of olive groves are owned by small holders in the olive growing countries, who earn enough for the betterment of their livelihood. Moreover, olive products help to satisfy the nutritional needs of the population. Ripe olive fruits are pressed for rich oil which is the best oil available in the world for edible purposes. The olive oil has twice as much energy value than sugar. The fruit contain around $20 \%$ oil and has very less cholesterol. Olive fruits contain $80 \%$ unsaturated fatty acid compared with $20 \%$ saturated ones. Olive oil contains high percentage of oleic acid which is very essential for our body. The olive oil is used for cooking, salad dressing, food preparation, massage and for the manufacture of cosmetics, pharmaceuticals, etc. Mature fruit are also eaten after being processed and preserved in vinegar or salt solution [3].

Olives have not been traditionally grown in Pakistan for the edible oil production, although few grooves existed both in the plain and hilly areas. The oldest cultivation was established in the 1970's. Therefore no scientific approach has been developed for their proper management and very limited research studies have been carried out on olive in this part of the world. The presence of millions of wild olive trees in the Federally Administered Tribal Area (FATA) of KP, Potohar and 
Northern Baluchistan indicates that the agro-climatic conditions of these areas are conducive for olive cultivation. In addition, different olive cultivars of Oleaeuropaea sub species sativa are successfully bearing fruits have also been introduced to various parts of Pakistan. Thus introducing a new crop such as olive that can be grown on marginal lands is inevitable to address the issue of income generation and halt natural resource degradation [4]. The wild plantation indicates that agro-climate of these areas, suitable for its commercial cultivation.

Olive is successfully grown in a climate having moderate cold winters and prolonged hot summers with low humidity. Temperature below $10{ }^{\circ} \mathrm{C}$ is injurious as it may kill the plant. Winter rest is considered essential for fruit bud differentiation. Most cultivars require at least two months of winter chilling for floral bud initiation. It is one of the most drought resistant trees and thrives well where the annual average rainfall is around 900-1000mm without irrigation. It grows well on many different kinds of soil, ranging from rocky shallow hillsides to deep fertile valley soils, from acid soils to fairly alkaline soils. It can also tolerate considerable salinity too. However it can't withstand poorly drained soils and quickly dies if water stands around its roots for few weeks [5].

\section{Objectives}

1. To study the effect of IBA on rooting ability of Olive.

2. Response of different cultivars to IBA.

3. To standardize optimum IBA concentration for Olive propagation through cuttings.

\section{Materials and Method}

The present study “The Response of Rooting of Various Olive Cultivars to IBA" was conducted at Agriculture Research Institute Tarnab Peshawar during the month of July, 2016. The experiment was laid out in Randomized Complete Block Design (RCBD) with single factors, three olive cultivars. The three cultivars were Coratina, Pendalino, Frantoio was selected for experiment. There were three replication. Pencil sized dormant hard wood cutting (15 to $20 \mathrm{~cm}$ ) of Olive were prepared and dipped for 2-3 seconds in IBA solution (3000ppm). The IBA $3 \mathrm{~g}$ was mixed with 0.5 Normal of $\mathrm{NaOH}$ solution to dissolve better in $1000 \mathrm{ml}$ distilled water. Different cuttings of the mentioned cultivars were taken from randomly ten selected trees. The trees selected for cuttings were of the same age healthy, well matured, and uniform and having vigorous growth. These selected trees were kept under proper cultural practices. The leaves and small branches were frequently thinned out from the each cuttings during the course of studies. The period of observation for rooting was monitored for 90 days.

The details of the experiment is as under.

$$
\text { Crop: Olive }
$$

Replicates $=3$

Cultivars $=3$ (Coratina,Pendalino,Frantoio)

Sampling per Replicate $=100$

Timing $=19^{\text {th }}$ July 2016

IBA Concentration $=3000 \mathrm{ppm}$

\section{Parameters Studied}

During the experiment, data were collected on the following parameters.

\section{Sprouting (\%)}

Rooted cuttings (\%)

Root Length $(\mathrm{cm})$

Successful Plants (\%)

\section{Sprouting (\%)}

Those cuttings were counted which were sprouted and the percentage was calculated with the following formula.

$$
\text { Sprouting } \%=\frac{\text { No. of Sprouted cuttings x } 100}{\text { Total No. of cuttings }}
$$

\section{Rooted cuttings (\%)}

The Rooted cuttings (\%) were counted in each treatment and percentage was determined with the following formula.

$$
\text { Rooted cutting }(\%)=\frac{\text { No. of Rooted cuttings (\%) } \times 100}{\text { Total No. of cuttings }}
$$

\section{Root Length (cm)}

The root length was data was recorded with the help of ruler and then average was calculated.

\section{Successful Plant (\%)}

The success percentage data was recorded according to the formula.

$$
\text { Success } \%=\frac{\text { No. of successful cutting } \times 100}{\text { Total No. of cutting }}
$$

\section{Results and Discussion}

A research study "Response of Rooting of Various Olive Cultivars to IBA" was carried out at Agriculture Research Institute Tarnab, Peshawar in 2016. Data recorded on the various parameters is presented in the Table 1-8. Whereas, the analysis of variance is given in ANOVA (Table 2,4,6,8). The result of each parameter is briefly described as under.

\section{Sprouting (\%)}

Data regarding Sprouting (\%) is presented in Table 1, the analysis of variance is placed in Table 2, the analysis of variance showed that planting dates had significant effect on 
Sprouting (\%). Comparison of means for Sprouting (\%) showed that maximum number of sprouts (84.6) were recorded for cultivar Coratina, and followed by cultivar Frantoio (81.3) while minimum sprouts (62.3) were recorded for cultivar Pendalino. The difference in Sprouting (\%) at same planting time might be attributed to the environment conditions as well as to the reserve food in cutting which were reported as Table 1. Figure 1 [6].

Table 1: Mean data for sprouting (\%) as affected by various olive cultivars.

\begin{tabular}{|c|c|c|c|c|}
\hline Cultivars & \multicolumn{3}{|c|}{ Iba 3000ppm } & Mean \\
\hline & R1 & R2 & R3 & \\
\hline CORATINA & 85 & 86 & 83 & $84.6 \mathrm{a}$ \\
\hline PENDALINO & 65 & 60 & 62 & $62.3 \mathrm{c}$ \\
\hline FRANTOIO & 83 & 81 & 80 & $81.3 \mathrm{~b}$ \\
\hline LSD $(0.05)$ & \multicolumn{5}{|c|}{3.663} \\
\hline
\end{tabular}

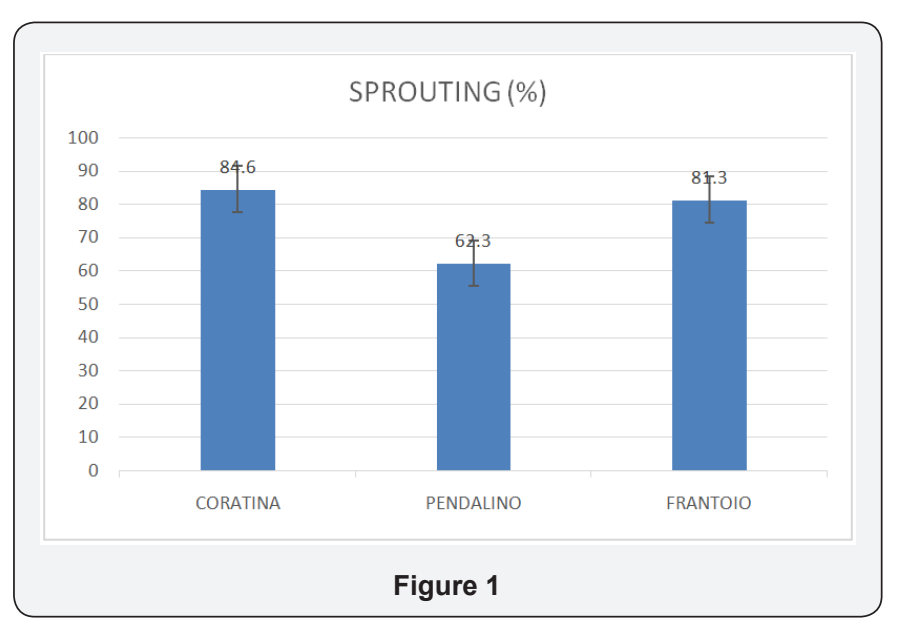

\section{Rooted cuttings (\%)}

Table 2: Analysis of variance for sprouting (\%) of olive cutting as effected by various cultivars.

\begin{tabular}{|c|c|c|c|c|c|}
\hline \multicolumn{7}{|c|}{ Source of } \\
\hline Variance & DF & SS & MS & F & P \\
\hline Replications & 2 & 11.556 & 5.778 & & \\
\hline Treatment & 2 & 870.889 & 435.444 & 166.77 & 0.0001 \\
\hline Error & 4 & 10.444 & 2.611 & & \\
\hline Total & 8 & 892.889 & & & \\
\hline
\end{tabular}

$\mathrm{CV}=2.12$

The data regarding rooted cutting (\%) is presented in Table 3 and the analysis of variance is given in table 2 a.Comparison of means for Rooted cuttings (\%) showed that maximum Rooted cuttings (\%) (38.3) were recorded for cultivar Coratina and followed by cultivar Frantoio (32.6) while minimum Rooted cuttings (\%) (16.1) were recorded for cultivar Pendalino Figure 2. The difference in rooted cuttings (\%) might be attributed to the nutrients in media as well as to the reserve food in cutting and quick water loss from the cutting which were reported as $[3,7,8]$. Table 3 .

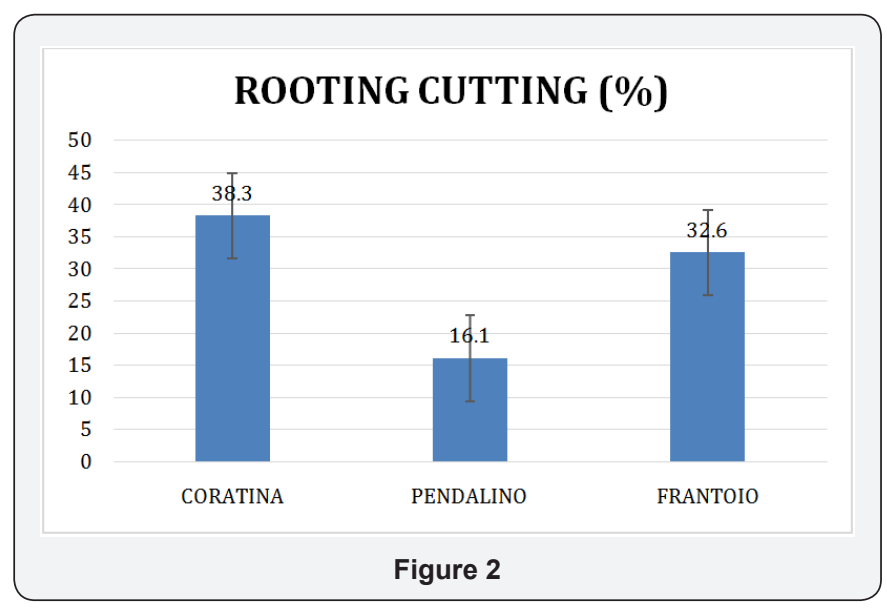

Table 3: Mean data for rooted cuttings (\%) as affected by various olive cultivars.

\begin{tabular}{|c|c|c|c|c|}
\hline Cultivars & \multicolumn{3}{|c|}{ IBA 3000ppm } & Mean \\
\hline & R1 & R2 & R3 & \\
\hline CORATINA & 37 & 39 & 39 & $38.3 \mathrm{a}$ \\
\hline PENDALINO & 17 & 15 & 17 & $16.1 \mathrm{c}$ \\
\hline FRANTOIO & 31 & 34 & 33 & $32.6 \mathrm{~b}$ \\
\hline LSD (0.05) & \multicolumn{5}{|c|}{3.022} \\
\hline
\end{tabular}

Table 4: Analysis of variance for rooted cutting of olive cutting as affected by various olive cultivars.

\begin{tabular}{|c|c|c|c|c|c|}
\hline \multicolumn{7}{|c|}{ Source of } \\
\hline Variance & DF & SS & MS & F & P \\
\hline Replications & 2 & 2.8889 & 1.444 & & \\
\hline Treatment & 2 & 782.889 & 391.444 & 220.19 & 0.0001 \\
\hline Error & 4 & 7.111 & 1.778 & & \\
\hline Total & 8 & 792.889 & & & \\
\hline
\end{tabular}

CV 4.58

Table 5: Mean data for root length $(\mathrm{Cm})$ as affected by various olive cultivars.

\begin{tabular}{|c|c|c|c|c|}
\hline & \multicolumn{3}{|c|}{ IBA 3000ppm } & \\
\hline CULTIVARS & R1 & R2 & R3 & MEAN \\
\hline CORATINA & 11 & 10.1 & 11 & $10.7 \mathrm{c}$ \\
\hline PENDALINO & 35 & 5 & 7 & $15.6 \mathrm{~b}$ \\
\hline FRANTOIO & 89 & 9.9 & 10 & $36.3 \mathrm{a}$ \\
\hline LSD (0.05) & \multicolumn{5}{|c|}{52.086} \\
\hline
\end{tabular}


Table 6: Analysis of variance for root length $(\mathrm{Cm})$ of olive cutting as effected by various cultivars.

\begin{tabular}{|c|c|c|c|c|c|}
\hline \multicolumn{7}{|c|}{ Source of } \\
\hline Variance & DF & SS & MS & F & P \\
\hline Replications & 2 & 2617.56 & 1308.78 & & \\
\hline Treatment & 2 & 1105.76 & 552.88 & 1.05 & 0.4307 \\
\hline Error & 4 & 2111.59 & 527.9 & & \\
\hline Total & 8 & 5834.91 & & & \\
\hline
\end{tabular}

CV 109.99

\section{Root length $(\mathrm{Cm})$}

The data regarding rooted length is presented in Table 5 and the analysis of variance is given in Table 6 [9]. Comparison of means for Rooted cuttings (\%) showed that maximum rooted length $(92.20 \mathrm{~cm})$ were recorded for cultivar Frantoio and followed by cultivar Pendalino $(39.62 \mathrm{~cm})$ while minimum rooted length $(27.17 \mathrm{~cm})$ were recorded for cultivar Coratina [10]. Maximum root length might be due to the proper availability of photosynthate and micro nutrients through which the root gain length. Reported that availability of nutrients and photosynthesis root growth occur [11] Table 5,6. Figure 3.

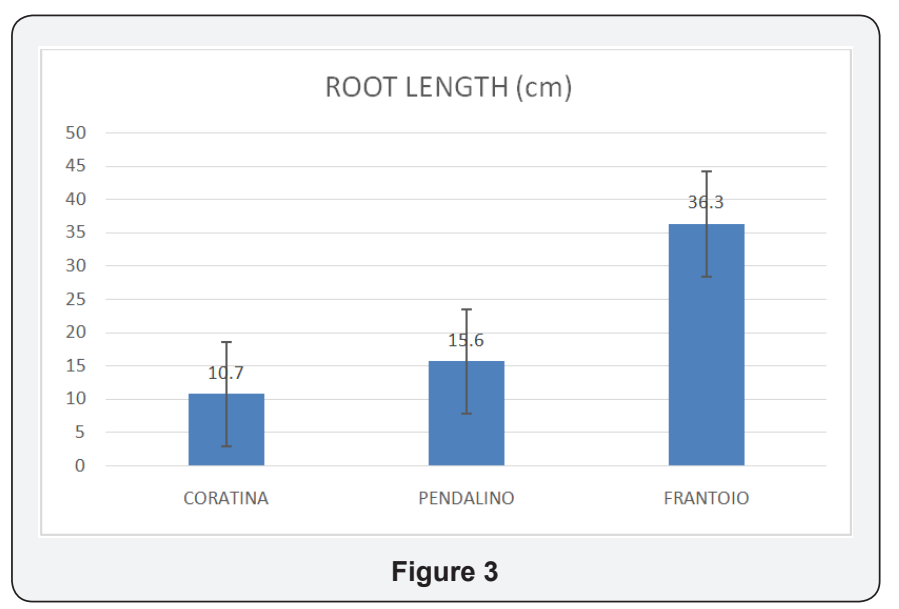

\section{Successful plant (\%)}

Table 7: Mean data for successful plant (\%) as affected by various olive cultivars.

\begin{tabular}{|c|c|c|c|c|}
\hline & \multicolumn{3}{|c|}{ IBA 3000ppm } & \\
\hline CULTIVARS & R1 & R2 & R3 & MEAN \\
\hline CORATINA & 31 & 32 & 34 & $32.3 \mathrm{a}$ \\
\hline PENDALINO & 12 & 13 & 10 & $11.6 \mathrm{c}$ \\
\hline FRANTOIO & 29 & 27 & 29 & $28.3 \mathrm{~b}$ \\
\hline LSD $(0.05)$ & 3.89 & & & \\
\hline
\end{tabular}

The data regarding successful plant (\%) is presented in Table 7 and the analysis of variance is given in Table 8. Comparison of means for successful plant (\%) showed that maximum successful plant (\%) (32.3) were recorded for cultivar Coratina and followed by cultivar Frantoio (28.3) while minimum successful plant (\%) (11.6) were recorded for cultivar Pendalino [12]. Maximum successful plant (\%) might be due to the proper availability of photo synthate and micro nutrients through which the root gain length. Reported that availability of nutrients and photosynthesis root growth occur [13] Table 7 \& 8 Figure 4 .

Table 8: Analysis of variance for Successful plant (\%) of olive cutting as affected by various olive cultivars.

\begin{tabular}{|c|c|c|c|c|c|}
\hline \multicolumn{7}{|c|}{ Source of } \\
\hline Variance & DF & SS & MS & F & P \\
\hline Replications & 2 & 0.222 & 0.111 & & \\
\hline Treatment & 2 & 720.889 & 360.444 & 122.42 & 0.0003 \\
\hline Error & 4 & 11.778 & 2.944 & & \\
\hline Total & 8 & 732.889 & & & \\
\hline
\end{tabular}

\section{7.12}

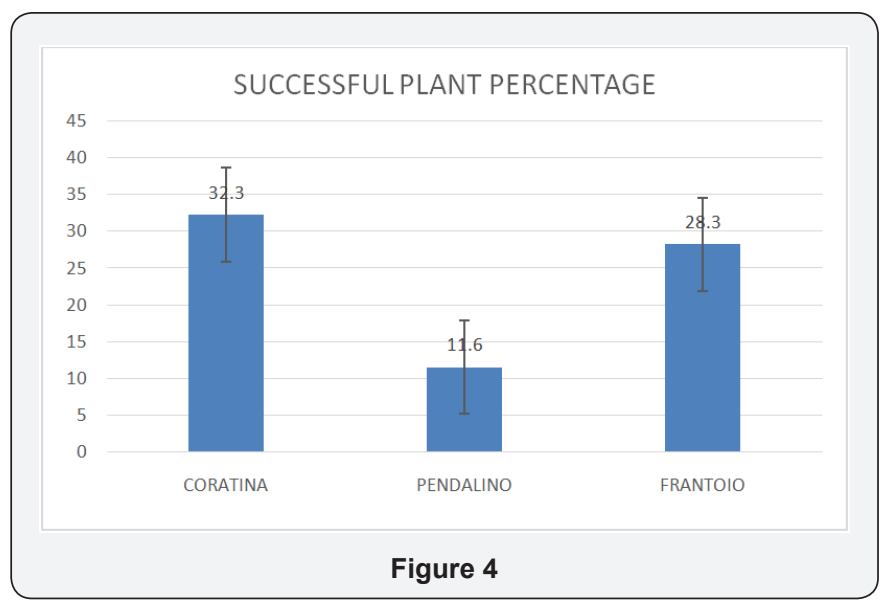

\section{Conclusion}

On the basis of the above recorded data the following conclusion can be drawn. Coratina is suitable cultivars at 3000 ppm IBA concentration for cutting of Olive propagation because it shows maximum number of sprouted cutting, rooted cutting, root length, successful plant percentage.

\section{Recommendation}

Coratina was good Olive propagated cultivar through cutting with the IBA concentration $3000 \mathrm{ppm}$ under the agro-climatic condition of Tarnab Peshawar.

\section{References}

1. Sajjad A, Wahid F, Muhammad S, Ibrar H, Saeed A, et al. (2014) Propagation of Olive Cultivars through Air Layerage. Journal of Agriculture and Veterinary Science 7(2): 121-125.

2. Riaz A, Ur Rahman K, Ilyas M, IMA Rauf (2007) Effect of Indole Butyric Acid Concentrations on the rooting of kiwi cuttings. Sarhad J Agric 23(2): 293-296.

3. Aslmoshtaghi E, Reza Shahsavar A, Reza Taslimpour M (2014) Effects of IBA and Putrescine on Root Formation of Olive Cuttings. Agriculturae Conspectus Scientificus 79(3): 191-194. 
4. Inam-ul-Haq, Ahmad T, Hafiz IA, Abbasi NA (2009) Influence of micro cutting sizes and IBA concentrations on In vitro rooting of olive cV. 'DolceAgogia'. Pakistan Journal of Botany 41(3): 1213-1222.

5. Hassan IT, Ahmad IA, Hafiz NA, Abbasiand BR (2008) Effect of Various Auxin Treatments (Indole Butyric Acidand Naphthalene Acetic Acid) on Root Initiation of Olive Cultivars, Coratina and Carolea. Asian Journal of Chemistry 20(8): 6509-6517.

6. Andreia H, Eduardo NC, Elizabeth 00, Sheila Zambello de Pinho (2006) Effect of Plant growth regulators in the rooting of Pinus Cuttings. Braz arch biol technol 49(2): 189-196.

7. Kurd AA, Amanullah S, Khan BH, Shahand MA (2010) Effect of Indole Butyric Acid (IBA) on Rooting of Olive stem cutting. Pakistan J Agric Res 23(3-4): 193-195.

8. Saleem MK, Fazli W, Javed I, Muhammad R, Muhammad A (2001) IBA Promotes Rooting in the Hardwood Cuttings of Olive (Olea europaea L.) Cultivars. Pakistan Journal of Biological Sciences 4 (6): 633-634.
9. Rafi-ur-Rehman, Shah AH, Awan AA, Hammad Ali (2013) Response of olive cultivars to rooting through air layering in different growth media. Sarhad Journal of Agriculture 29(1): 1-5.

10. Rymbai H, Reddy GS (2010) Effect of IBA, time of layering and rooting media on air-layers and plantlets survival under different growing nursery conditions in guava. Indian J Hort 67: 99-104.

11. Mehri S, Vahid RS (2012) Effects of media and indole butyric acid (IBA) concentrations on hopbush (Dodoneae viscose L.) cuttings in green house. Annals of Forest Research 55(1): 61-68.

12. Shahab M, Ayub G, Rahman A, Rashid AA, Jamal, et al. (2013) Assessment of IBA (Indole Butyric Acid) Levels and Planting Time for Rooting and Growth of Alstonia Cuttings. J of Nat Sci 3(14): 59-67.

13. Ullah E, Awan AA, Abbas SJ, Masroor FS, Khan O (2012) Growth response of various olive cultivars to different cutting lengths. Pak J bot 44(2): 683-686

\section{Your next submission with Juniper Publishers} will reach you the below assets

- Quality Editorial service

- Swift Peer Review

- Reprints availability

- E-prints Service

- Manuscript Podcast for convenient understanding

- Global attainment for your research

- Manuscript accessibility in different formats

( Pdf, E-pub, Full Text, Audio)

- Unceasing customer service

Track the below URL for one-step submission https://juniperpublishers.com/online-submission.php 